University of Nebraska - Lincoln

DigitalCommons@University of Nebraska - Lincoln

$11-23-1988$

\title{
Colony Survivorship in Pogonomyrmex occidentalis, Western Harvester Ant, in Western Nebraska
}

Kathleen H. Keeler

University of Nebraska - Lincoln, kkeeler1@unl.edu

Follow this and additional works at: https://digitalcommons.unl.edu/bioscifacpub

Part of the Biodiversity Commons, Entomology Commons, Population Biology Commons, and the Terrestrial and Aquatic Ecology Commons

Keeler, Kathleen H., "Colony Survivorship in Pogonomyrmex occidentalis, Western Harvester Ant, in Western Nebraska" (1988). Faculty Publications in the Biological Sciences. 286.

https://digitalcommons.unl.edu/bioscifacpub/286

This Article is brought to you for free and open access by the Papers in the Biological Sciences at DigitalCommons@University of Nebraska - Lincoln. It has been accepted for inclusion in Faculty Publications in the Biological Sciences by an authorized administrator of DigitalCommons@University of Nebraska - Lincoln. 
Keeler in Southwestern Naturalist (November 23, 1988) 33(4).

Copyright 1988, Southwestern Association of Naturalists. Used by permission.

\section{COLONY SURVIVORSHIP IN POGONOMYRMEX OCCIDENTALIS, WESTERN HARVESTER ANT, IN WESTERN NEBRASKA}

Little is known about the life span of individual ant colonies (Keeler, 1981), even though the dynamics of some species, such as harvester ants, are crucial to the structure of plant and animal communities (e.g., Brown et al., 1979). This note reports the results of 10 years of observations on a population of harvester ants.

TABLE 1-Annual colony recruitment, colony death, and total number of colonies in pasture harvester ant population.

\begin{tabular}{lccc}
\hline Year & Number recuited & Number died & $\begin{array}{c}\text { Number of } \\
\text { colonies }\end{array}$ \\
\hline 1977 & & & 56 \\
1978 & 10 & 1 & 65 \\
1979 & 4 & 1 & 68 \\
1980 & 3 & 3 & 68 \\
1981 & 3 & 1 & 70 \\
1982 & 8 & 2 & 76 \\
1983 & 3 & 1 & 79 \\
1984 & 0 & 2 & 77 \\
1985 & 0 & 5 & 72 \\
1986 & 7 & 2 & 77 \\
\hline
\end{tabular}




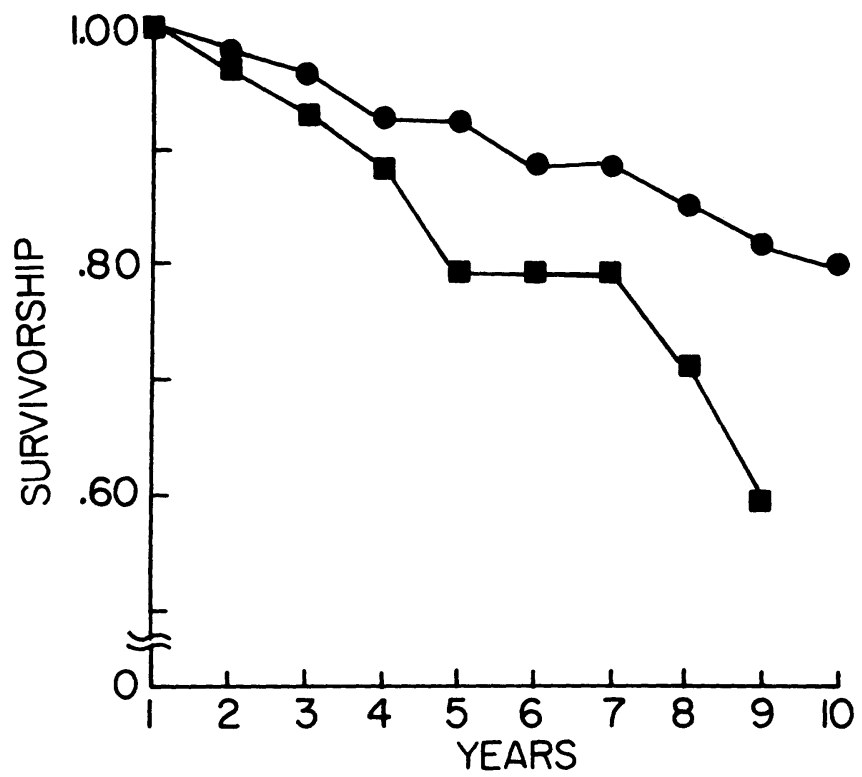

Fig. 1-Survivorship curves for a population of Pogonomyrmex occidentalis colonies. Dots = original cohort (56 colonies) marked in 1977. Squares = survivorship of new colonies, calculated from the fate of colonies added since 1977. Years (1 to 10) represent age of colonies (1977 to 1986). Since survival was calculated from all data available on colonies of a given age, more information exists for younger ages.

Fifty-six mounds of Pogonomyrmex occidentalis Cresson (Hymenoptera: Formicidae), western harvester ant, were permanently marked with aluminum tags in August 1977. The site, about 1 ha just south of the University of Nebraska's Cedar Point Biological Station, Keith Co., Nebraska, was within a pasture subject to moderate, half-summer grazing. The vegetation was typical shortgrass prairie, dominated by buffalo grass (Buchloe dactyloides) and hairy and smooth grama grasses (Bouteloua hirsuta and Bouteloua gracilis) interspersed with needle-and-thread grass (Stipa comata) and forbs such as Yucca glauca (Kaul et al., 1983). Each August from 1977 to 1987, the population was censused, deaths noted and new colonies marked.

Of 56 colonies marked in 1977, 45 were still alive in 1986, which is an average death rate of 0.02 colonies/year. If one assumes a stable population in which recruitment balances mortality, this survival of $\mathbf{8 0 . 3 \%}$ over a decade implies a life expectancy, for an established colony, of 50.9 years.

Life expectancy can also be estimated from recruitment (appearance of new colonies) and death of colonies. Recruitment by year is shown in Table 1 . The term recruitment is used to mean the discovery of a colony with foragers that had not been seen in previous years. Newly mated harvester queens begin nest building in late July or early August in this area (Gregg, 1963) so a newly founded colony has been at the site at least a year when discovered. Using the average. of recruitment rates calculated for each year, the mean recruitment was 0.056 colonies/year $(S E=$ 0.042). Two large colonies, first marked in 1978, were clearly not new and were excluded from the calculations. If the population were in equilibrium, so that recruitment balanced death over the period, this rate of recruitment would imply a mean life expectancy of 17.8 years from the time of establishment.

Colony deaths observed each year are also given in Table 1. Calculated as mean death rates for the particular year's population, these give an average value of 0.028 deaths/year $(S E=0.017)$, which, projected to a stable population, suggests a life expectancy of 35.7 years. The value based on death rates is lower than that from birth rates. This seems reasonable because the population has shown net growth over the study period. These values are similar to those calculated for 5 years of observations of the same population (Keeler, 1981). 
New colonies had a higher death rate than established ones. The cohort present at the beginning of the study had a net death rate of 0.02 /year. The death rate for 29 colonies recruited since 1977 was 0.027 , implying a life span of 36.3 years. This figure was calculated omitting several colonies from the margins of the population which were clearly long-established when found, although first marked after 1977. Survivorship curves of both groups are presented in Fig. 1 .

While there are substantial differences between the estimates, it is clear that most established colonies of western harvester ants live several decades. The data further suggest that assumptions of equilibrium are in fact flawed, since the population grew $27 \%$ during the study period. This growth is not easily explained by climate, since, in the last decade, as many years have had below average rainfall as above (United States Department of Commerce, 1976-1986) and the grazing regime has not changed substantially (K. H. Keeler, pers. obser.; B. L. Gainsforth, pers. comm.).

Estimates of survivorship based on death rates may be more reliable than those derived from recruitment; if I missed a new colony for 2 years, it introduced a substantial error, since there are only 10 years of observations. Such errors are difficult to eliminate, whereas the death of marked ant colonies is unambiguous.

I thank B. L. Gainsforth for permitting the study on his property. R. Ballinger made helpful comments on the manuscript.

\section{Literature Cited}

Brown, J. H., O. J. Reichman, and D. W. Davidson. 1979. Granivory in desert ecosystems. Ann. Rev. Ecol. Syst., 10:201-227.

Gregg, R. E. 1963. The ants of Colorado. Univ. Colorado Press, Boulder, Colorado, 792 pp.

Kaul, R. B., Challaiah, and K. H. Keeler. 1983. The effects of grazing and juniper canopy closure on the prairie flora in Nebraska high plains canyons. Pp. 95-105, in Proceedings of the seventh prairie conference (C. Kucera, ed.). Univ. Missouri, Columbia, $321 \mathrm{pp}$.

KeELer, K. H. 1981. Preliminary report of colony survivorship in the western harvester ant (Pogonomyrmex occidentalis) in western Nebraska. Southwestern Nat., 27:245-6.

United States Department of Commerce. 1977-1986. Climatological data, Nebraska. Natl. Climatic Center, Asheville, North Carolina, vols. 80-91.

K. H. KEELER, School of Biol. Sci., Univ. of Nebraska, Lincoln, NE 68588-0343. 